\title{
Psychospiritual impact of COVID-19: Africentric Perspectives
}

\section{Therese Mungah Shalo Tchombe PhD \\ Email: tmtchombe@yahoo.co.uk \\ P.O. Box 901, Limbe, Cameroon}

\begin{abstract}
This study sought to find out the psychospiritual impact of COVID-D as a result of the imposition of preventive measures. The study was carried out in the Mezam Division of the North West Region of Cameroon. A mixed research approach was used for the study with the aid of a questionnaire and an interview guide. A convenient sampling technique was chosen for the study based on the availability of the 50 respondents chosen for the study, using the snowball technique. The results of the study reveal that the most acceptable preventive measures that people complied to were personal hygiene (100\%), taking of African traditional concoction treatments (100\%) and prayers to God (100\%). Psychologically, $60 \%$ of the respondents expressed symptoms of anxiety, while $30 \%$ expressed symptoms for stress and $20 \%$ expressed symptoms of depression. Spiritually, all 50 respondents $(100 \%)$ indicated that their spiritual activities have been disrupted by the pandemic, which poses a real problem for an African oriented society where religion and spiritual activities are common. In conclusions, it was evident that psychospiritual dissonance including mixed and faulty beliefs on those claiming to provide solutions complicated peoples' understanding of the realities of the situations.
\end{abstract}

Key Concepts: COVID-19, Psychological impact, Spiritual impact

Received: 01/07/2021
Accepted: 06/11/2021
DOI: https://dx.doi.org/10.4314/jcas.v17i2.5
C The Author. This work is published under the Creative Commons Attribution 4.0 International Licence.


Résumé

La présente étude avait pour but de rechercher l'impact psycho-spirituel de la COVID-19 à la suite de l'imposition de mesures préventives. L'étude a été réalisée dans le département de la Mezam dans la région du Nord-Ouest du Cameroun. Une approche de recherche mixte a été utilisée pour l'étude à l'aide d'un questionnaire et d'un guide d'entretien. La technique d'échantillonnage par choix raisonné a été adoptée pour l'étude en fonction de la disponibilité des 50 répondants sélectionnés notamment en utilisant la technique de la boule de neige. Les résultats de l'étude révèlent que les mesures préventives auxquelles les gens se conforment sont celles relatives à l'hygiène personnelle (100\%), à la prise de décoctions traditionnelles (100\%) et les prières à Dieu (100\%). Psychologiquement, 60\% des répondants ont manifesté des symptômes d'anxiété, tandis que 30\% ont manifesté des symptômes de stress et 20\% ont manifesté des symptômes de dépression. Spirituellement, les 50 répondants (100\%) ont indiqué que leurs activités spirituelles ont été perturbées par la pandémie, ce qui pose un réel problème pour une société à vocation africaine où la religiosité et les activités spirituelles sont inestimables. En conclusion, il était évident que la dissonance psycho-spirituelle, y compris les croyances mitigées et erronées de ceux qui prétendaient apporter des solutions, compliquait la compréhension que les gens pouvaient avoir de la réalité de la situation.

Concepts clés : COVID-19, impact psychologique, impact spirituel 


\section{INTRODUCTION}

COVID-19 has posed great challenge to humans across the world with new global health crisis threatening all aspect of life and development. Many supportive and symptomatic therapies are being carried out by Medical Practitioners as per the instructions of WHO (Dwarakesh, Ananda, Asifa, Bhaskar \& Brito, 2020). Owing to the lack of proper definitive treatments, the virus continues to pose a great challenge in the field of medicine, research, economic, public health, and others (Dwarkesh et al, 2020). As pointed out by these authors, there is yet no universal acceptable therapy and vaccine against this virus. According to $\mathrm{WHO}, 80 \%$ of the community in developing nations continues to depend on indigenous medicine. This complementary and alternative medicine may help to unwrap the mysteries and complications behind COVID -19, as this herbal medicine accommodates a variety of herbs with medicinal value owing to their own broadspectrum antiviral activity (Dwarkesh et al, 2020). From their observations and as instructed by WHO, the best approach to lower the current crises of infection is prevention and many measures that can boosts the immunity, including personal hygiene.

In Cameroon, preventive and medical actions are the most important intervention strategies used by the government (Ministry of Public Health, 2020). Nonetheless, emerging psychological and traditional interventions for people affected by COVID-19 are also critical and awaited. According to the Ministry of Health statistics as per August, 2021 Cameroon currently has 61731 confirmed cases; 919 deceased; 56926 remissions and 3886 active cases.

While most studies on COVID-19 are limited physical and health related issues, this study rather focuses on the psychospiritual impact of COVID19. Psychologically, people are trying to internalise the understanding of this phenomenon that generates such arrays of emotions, as anxiety, depression and stress. Depression is used to describe a range of moods - from low spirits to a severe problem that interferes with everyday life. The experience of depression is an overwhelming feeling which can make you feel quite unable to cope, and hopeless about the future. If you are depressed, your appetite may change and you may have difficulty sleeping or getting up. You may feel overwhelmed by guilt, and may even find yourself thinking about death or suicide (Borrill, 2000). Anxiety is the total response of a human being to threat or danger. Each experience of anxiety involves a perception of danger, thoughts about harm, and a process of physiological alarm and activation. The accompanying behaviours display an emergency effort toward "fight or flight" (Moss, 2002). Stress can be considered as any type of change that causes physical, emotional, or psychological strain. Stress arises when individuals perceive that they cannot adequately cope with the demands being made on them or with threats to their well-being (Lazarus, 1966). Spiritually, and from an African centric perspective individuals pray, meditate, and invoke the ancestors through sacrifices in the hope that they will see it through trying times. Hence, in typical African societies, the outbreak of a disease like COVID-19 was always a call for spiritual concern. In this regard sacrifices and spiritual gifts will be offered to the gods and ancestors for appeasement, with the hope that the ancestors will intercede on behalf of the people to the Almighty God. Prevention and treatment measures of illnesses were both natural and spiritual, whereby both the natural herbs and spiritual forces come into play for the complete healing of the entire society. Within the outbreak of COVID19, the imposition of physical distancing and closures of churches and other worship arenas rather poses spiritual emptiness for Africans. 
Because of the uncertainties and paradoxes of COVID-19 and its preventive measures, this paper sought to examine the impact of the pandemic on the psychospiritual wellbeing of people in Mezam Division of the North West Region of Cameroon. Specifically, the study was geared towards the following objectives:

- To examine the people's compliance to the various preventive measures available to reduce the spread of COVID-19 in Mezam division of the North West Region of Cameroon.

- To examine the impact of COVID19 on the psychological wellbeing of people in Mezam division of the North West Region of Cameroon.

- To examine the impact of COVID19 on the spiritual wellbeing of people in Mezam division of the North West Region of Cameroon

\section{MATERIALS AND METHODS}

In this section, we shall focus on the research design, study area, sample, instruments, methods collection, and analysis used for the study.

\section{Research design}

A mixed method research design was chosen for the study. This involved the use of both qualitative and quantitative approaches in a sequential process. Hence a concurrent mixed design was adopted, whereby qualitative data was collected at the same time with quantitative data collection. A mixed method was used because the various objectives of the study required both qualitative and quantitative collection of data. Phenomenology method was chosen for data collection so as to investigate the variations of the impact of COVID-19 as they occurred during the time of study. Hence an interview guide, closed ended questionnaire and psychometric test were used for the study.
Study area, sample and sampling technique This research was done in the Mezam Division in the North West Region of Cameroon. Mezam is a division of the North West Region of Cameroon. The department covers an area of $1745 \mathrm{~km} 2$ and as of 2005 had a total population of 524,127. The study focused on Bamenda III municipality of Mezam Division. Bamenda III Council was created in 2007 by Presidential Decree. No. 2007/ 115 of 23rd April 2007. The population of Bamenda III municipality is largely cosmopolitan made up of indigenous $\mathrm{Nkwen}$ and $\mathrm{Ndzah}$ people, migrants from all over the North West and West Regions, other regions of Cameroon and Nigerians. The total surface area of Bamenda is 22.9 $\mathrm{Km} 2$ hectares and its estimated population stands at 105.244 (according to projection by CAMGIS in Minimum Urban Local Development Scheme (SMAUL) February 2008). A convenient sample of 50 respondents were chosen for the study based on the availability of the respondents and willingness to participate in the study.

Instruments for data collection

Three instruments were used to collect data. The first was an interview guide. This guide was designed to measure the impact of COVID-19 on the spiritual wellbeing of people. The second instrument was a questionnaire that was designed to measure people's compliance to the various preventive measures of COVID-19. The third instrument was a psychometric test adapted from DAS-42, Lazarus and Folkman (1984), designed to measure the impact of COVID-19 on the psychological wellbeing of people.

Validity of instruments and methods of data analysis

Content validity was used to validate instruments which is based on how the content of the instruments corresponded to the content of the theoretical concept they were designed to measure. Content validity was therefore 
mathematically appreciated using the Content Validity Index (CVI) whereby the instruments for data collection were checked by three experts. To come out with the statements that an instrument is judged valid, the inter-judge coefficient of validity was computed using the following formula: CVI $=($ No of judges declared item valid)/ (total No of judges). The above 0.75 , CVI obtained for this study was declared satisfactory. Qualitative data was analysed using a systematic process of thematic content analysis while quantitative data analysis was based on descriptive statistics.

Ethical considerations

The informed consent of the respondents was solicited and the researcher made sure they were

Objective one: People's compliance to the various preventive measures of COVID-19

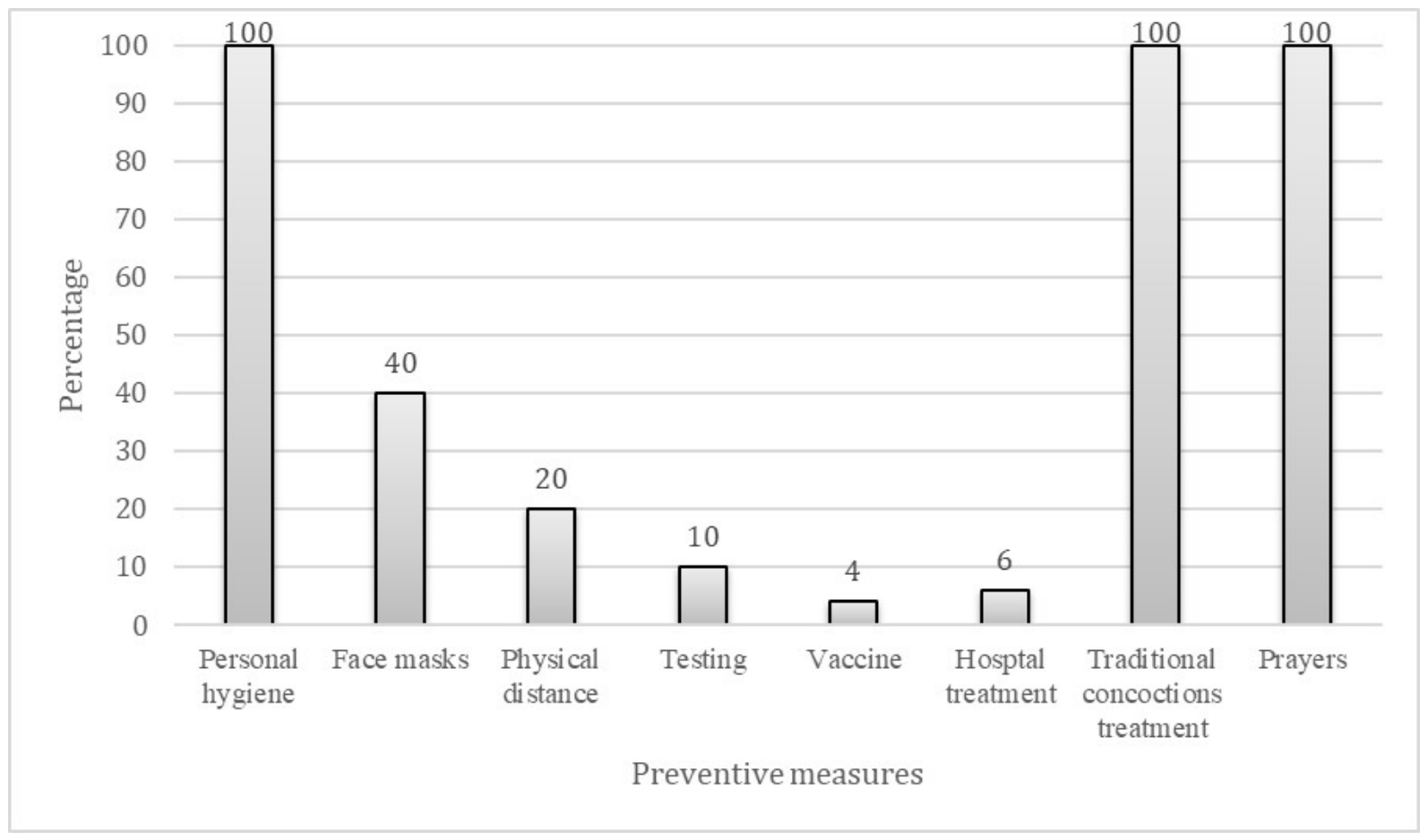

Figure 1: Percentage of respondents' compliance to various preventive measures

From the results above, it can be inferred that out of the 8 preventive measures selected for this study, the most acceptable measures that people complied to were personal hygiene (100\%), taking African traditional concoction treatments $(100 \%)$ and prayers to God $(100 \%)$. Only $2(40 \%)$ of the respondents accepted to take vaccines if available, while only $5(10 \%)$ were willing to do a COVID-19 test and only $3(6 \%)$ accepted they could be hospitalised and given hospital treatment. 
Objective two: The impact of COVID-19 on the psychological wellbeing of people

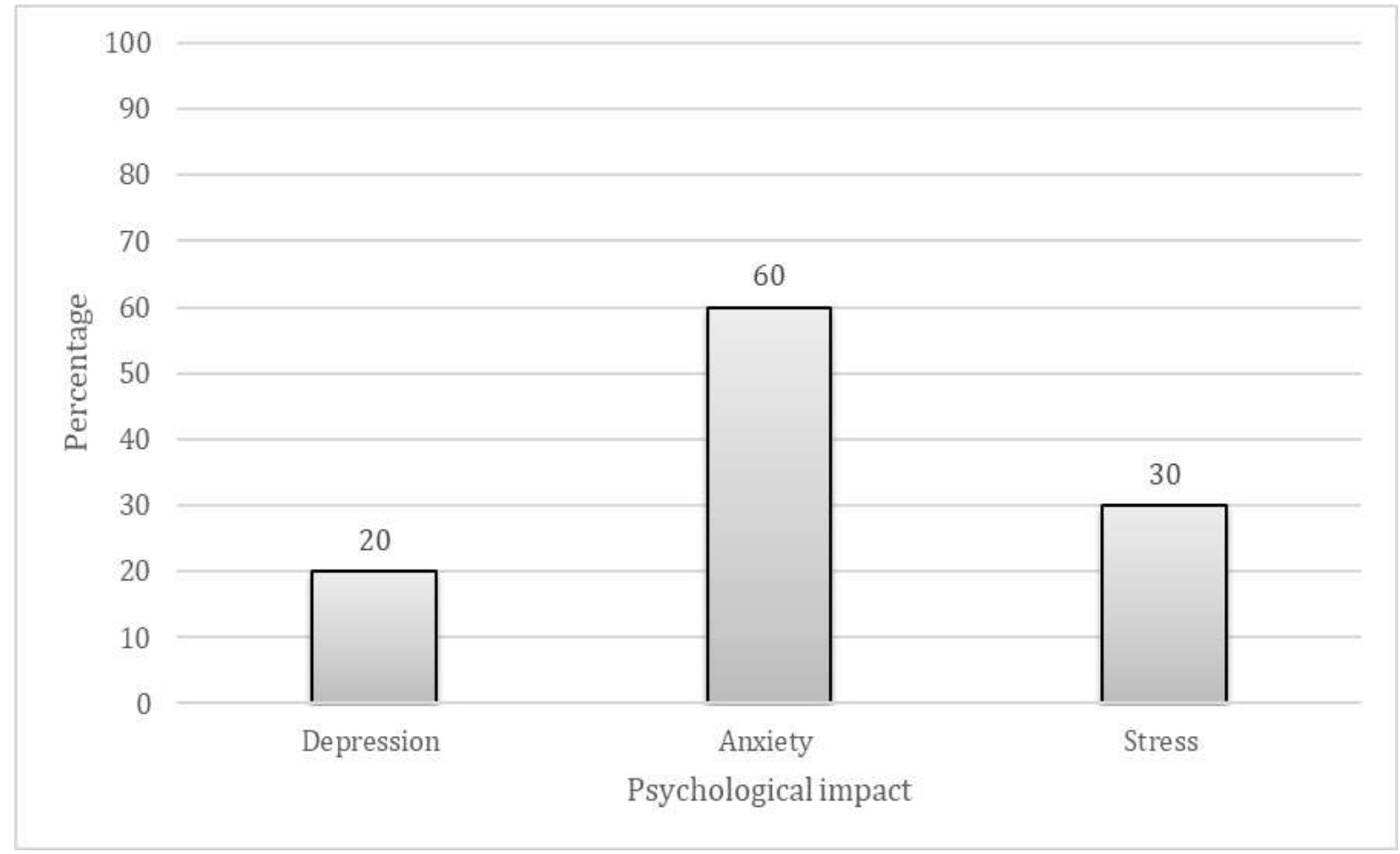

Figure 2: Percentage of psychological symptoms expressed by respondents

From the results above, it can be inferred that more respondents showed symptoms of anxiety (60\%) than stress (30\%) and depression (20\%)

Objective three: The impact of COVID-19 on the spiritual wellbeing of peoples

According to qualitative information from respondents the pandemic is indeed "scary." It has not only brought harm but some good in disguise. It has made people see how meaningful life is and the valueless of money and material possessions. People now live practically knowing that they can die any time and so must trust God as the author and finisher of their life and faith. "Standing in awe of His supremacy and grace, I now value life and thank God for each day I see".

On a positive note, a wife said "I am very happy, because my busband during lock down is forced to stay bome with us. I have the opportunity to be with my busband and children creating a strong family bond as we are able to pray together for God's mercy and forgiveness".
Negatively, the spiritual lives of some Christians have dropped as they no longer go to church for fellowship. Some reflect on the pandemic asking why God allowed such calamity to befall His people, destroying the world. One respondent said, "God has forgotten about his people and does not care about them thus they have given up their faith". From the information gathered from what some people said during the interview, it is clear, that the pandemic is viewed with mix feeling as it comes with both positive and negative spiritual impacts.

\section{DISCUSSION}

From the findings of the study, COVID-19 has brought a drastic change in the social orientation of communities. Because of the imposition of social distancing and use of face masks as preventive measures, the social orientation of people has changed from communal to more of individualistic orientation. This new orientation 
is alien to African cultures and therefore poses psycho-spiritual effects, namely, depression, anxiety, and fear, as well as lack of spiritual worship and neglect of traditional/spiritual healing. COVID-19 can therefore be seen as an enigma if one can comfortably qualify it as such because of the uncertainties and paradoxes it creates in the domains of peoples' psychological and spiritual life:

Implications of preventive measures of COVID19

Within African cultures, spirituality and beliefs about the world enable the individual build inner strength to cope and be resilient (Turnbull, 1976). Illnesses of such magnitude claim many lives and can never be perceived just from a biological perspective that define only one way of intervening (Mbiti, 1969). There is a need for a holistic approach blending Africentric health approach to Eurocentric. Before Western medicine came into the continent, Africans had sophisticated medical approaches for healing (Tchombe, 2016). Some of these practices included the use of plants to heal pain, diarrhoea, and malaria confirmed in the 20th century (Van Sertima, 1983). Ancient African legacies are plenty and have had implications throughout the world in all aspects impacting humanity and development. It is a pity that some of the traditional treatments that have helped COVID19 patients in Douala, Cameroon, heal are being rejected (CRTV, 2020).

From informal discussions and observations of some persons in the South West region of Cameroon, and elsewhere who have contracted COVID-19, it was evident that some people do not trust western medicines in the treatment of COVID-19. On this account, they tend to revert to spiritual approaches and traditional treatments. The psychological dissonance created by this pandemic, breeds suspicion, lack of faith and trust including mixed and faulty beliefs on government and NGOs claiming to provide solutions. Pathways for treatment cannot be restrictive, since it is still not clear what exactly is being treated, given that the symptoms differ with certain persons. Accordingly, most people as observed and with whom I had conversations, refused to go to the hospital for fear of wrong diagnosis and treatment. Patients are afraid they will be left to die alone with none of their loved ones by their side.

Psychological implications of COVID-19

Psychologically, the implications on the affected and those not affected are numerous because these implications impact all aspects of life. The emerging challenges can turn into forms of denial because fear of the unknown makes people panic and suffer from different anxiety related concerns. Imposed restrictions increase fear and anxiety. The problems of social isolations, physical distancing, lockdown, vaccines, testing, face masks and engaging in usual socio-economic activities for most people become very difficult. As pointed out by Yao, Chen \& Xu (2020), World Health Organization has urged that the necessary precautions to tackle the negative impact of the spread of Coronavirus on psychological health and well-being be taken. Varshney, Parel, Raizada \& Sarin (2020), argued that constant support for mental and psychosocial well-being in different groups during the outbreak should be of highest priority. Patel \& Jernigan, (2020) postulated that providing psychological first aid and counselling are essential during an epidemic. It helps in reducing the psychological distress and promoting adaptive coping strategies to deal with the situation (Patel \& Jernigan, 2020).

The effects can also be seen where health systems, based practices and research do not engage the social sciences to understand how ill health can lead to complex behaviours not necessarily related 
to the illness thus deterring recovery. The lack of knowledge about illness conditions and behaviours that takes into consideration the interplay of cultural, social, and religious beliefs may hamper the healing or recovery process. Fear, depression, frustration, and anxiety represent consequences of the uncertainties caused by COVID-19 and these could be damaging as these affect the individual's mind theory, overwhelming its capacity to manage the challenges experienced. For those parents with children, their unpreparedness and inability to meet the needs of children growing up, such as access to quality education, balanced meals, and the monitoring of their children's sexual behaviour because of idleness, frustrates parents. These actions lead to younger children to lose their virginity and others become pregnant with their sibling's baby. Parents also feel that their frustration could be overcome through excessive intimate relationships with one another or engaging in excessive drinking. These situations render relationships with children challenging and with spouses perhaps feeling overbearing.

Rosmarin (2020), reiterates that people find it difficult to tolerate not knowing the next move in life, which is not being able to predict and control the future. This situation creates anxiety. The level of uncertainty in human life today is enormous as Rosemarin (2020) speaks about the impact of losing our daily routines, and how starting a new one can help alleviate anxiety. $\mathrm{He}$ focused on managing feelings during this period of COVID-19. As people live each day with the threat of contracting COVD-19, it heightens the level of anxiety. One of Rosemarin's findings from research showed that the quality of sleep alleviates $40 \%$ of a person's anxiety according to their data. Meditation also was seen to have an incredible power in the brain since the frontal cortex is very active all day long through thinking and trying to solve problems. Mediation enables an individual to reduce the energy spent on worrying by focusing on the moment through controlling all thoughts and just be.

Dimensions creating anxiety are many, such as avoiding being infected, protecting children and family and the desire to return to normality, which also require adequate psychosocial adequate preparedness in all aspects of social life. In grappling with this new trend, impacting lives negatively, there must be ways of how people should cope with uncertainty that has suddenly altered the normal lifestyles of different communities and age groups. Dr Hans Kluge (2020), says, the issue facing each and every one of us is how we manage and react to the stressful situation unfolding so rapidly in our lives and communities. Here we can draw on the remarkable powers of strength and cooperation that we also fortunately possess as humans. And that is what we must try to focus on to respond most effectively to this crisis as individuals, family, and community members, friends, and colleagues.

Spiritual implications of COVID-19

In this paper the issues of spirituality are raised as having value in building inner strength and support wellness. Miller \& Thoresen (1999) in defining health and spirituality anchored more on spiritual well-being as an important and too often overlooked dimension of health. These authors reiterated that spiritual and religious involvement is not only common but is often important in peoples' lives and has been generally linked to positive health outcomes. Koening (2012) on Religion, Spirituality, and Health, found out that $80 \%$ of research on religion and spirituality and health are concerned with mental health. This strong relationship is illustrative of the involvement that consists of psychological, social, and behavioural aspects that are interwoven with mental health than physical health. One may not expect direct effects of religion and spirituality on physical health except indirectly through 
psychosocial and behavioural pathways. An individual's level of spirituality can serve in some cases as a life enhancing factor and as a coping resource. This has been a very powerful inner strength for Africans (Turnbull, 1976).

This paper does not attempt to make any distinction between the two concepts of traditional religion and spirituality, but it will highlight that Africentric values, drawing much focus on African Traditional Religion/Spirituality and their implications on African traditional medicine. There is a lot of inspiration that impact the identification and production of African traditional medicine. In most African traditional settings, viruses like COVID-19 or any other epidemic plaguing a community, normally could be understood as evil spiritual forces, and so would require sacrifices to be offered to the ancestors and deities for cleansing. Perhaps as we speak, some communities are engaged in such practices to the extent that even hospital treatment intertwines with these practices.

It is important to note that the content of traditional heritage is derived from the spiritual environment whereby in healing, spiritual significance is important. Religion plays a key role in the life of Africans, by providing a rallying point for the community, backed up by socially accepted values and norms such as honesty, generosity, diligence and hospitality (Ocitti, 1971; Hiebert, Daniel \& Tite, 2001; Mbiti, 1991). In today's context, a pandemic such as the Coronavirus, a pandemic that kills many people (WHO, 2020), the spiritual effect seems not to have entered the conversation. Yet there is concern about those dying with no one to prepare or support them. In fact, this evokes concern about the state of an individual's soul. Spiritual well-being is alien to many people's daily lives, and with the decline of organized religion, people experience a sick soul, however you want to define it. Maslow's (1966) article on "Religions, values, and peak experiences" is worth reading for some orientations on the issue raised. In this current time therefore, there will be patients with weariness of heart, a sinking feeling and giving up without finding a way out, but with spiritual uplifting they can have peace.

Human beings tend to turn to prayer in a time of crisis. Unfortunately, religious places including mosques, churches, or temples are being closed. The weekly Friday prayers banned, masses suspended, and rituals curtailed. People may feel hopeless. Getting through these testing times will require a lot of 'spiritual innovations. Amid this situation, people are encouraged to stay back, pray from home, and use the liturgy and prayer resources provided (Salve, 2020).

African Traditional Religion teaches us that every person has a body and a soul and that the African is notoriously religious (Mbiti, 1969). The African cannot be separated from his/her religion. Within African cultures, diseases of high social impact, affecting almost everyone in the community were approached from a spiritual dimension. Sacrifices would be offered to the deities and ancestors to intercede to God almighty to redeem the land from such calamity. The paradox is the fact that the Cameroon government and international organisations rather emphasise health measures to the neglect of the spiritual. COVID-19 has received little or no spiritual attention. Rather, churches and schools have been closed, while markets, bars etc are left open. This is paradoxical because in a typical African way of doing things, such kind of diseases would gather the community around the shrines of the ancestors to offer sacrifices for cleansing.

The current neglect of the spiritual dimension contradicts African Traditional Spirituality that 
encourages interaction between nature, humans and the supernatural. As Mbiti (1969) highlights, spirituality cannot be cut off from the African world view because wherever the African is, there is religion. African traditional healing therefore goes beyond the physical to embrace the spiritual and it is this spiritual dimension that the world at large and the Cameroon government in particular, seem to neglect.

To sum up, the COVID-19 pandemic reminds us we are-deep down-spiritual beings, whether we realize it or not, and makes us recognize that the problem of coronavirus is right here at the face of our global community; it's a challenge that requires global cooperation and unity, a component of compassion to alleviate suffering, and a greater responsibility to exercise our faith to witness divine intervention (Salve, 2020).

\section{CONCLUSIONS}

This paper is a reflection of the psychospiritual outcomes of COVID-19 on the lives of peoples. It raises critical concerns regarding the challenges of an unsafe environment for healthy development. It also addresses the psychological conflicts such situation creates and its challenging effects on individual's emotions that are hampering healthy development or living. This paper also raises concerns about the negligence of African traditional healing approaches even as first aid. These should be brought into conversation as many are using these African traditional healing approaches with positive results. In addressing these curative measures, the paper raises issues related to religion or spirituality which could provide hope through faith. It is the contentions of the paper that one's level of spirituality can help overcome some of the emotional traumas caused by the Covid-19. Even the ability to manage the family setting can be enhanced by spiritual standing. The following are recommended based on the outcomes:
- Creation of more mental health and psychosocial support services and child protection services for the children of families.

- There is need also to consider, psycho-social dialogue in this discussion seen as an empowering strategy for individuals to develop management skills, through meaningful participatory interactions on a one-to-one basis or in small groups with professionals and trustworthy persons.

- Further, emphasis should be placed on how governments establish evidence-based strategies to improve public and clinical intervention systems and provide psychosocial support and safe spaces in schools for all.

\section{ACKNOWLEDGEMENTS}

I am most grateful to the Cameroon Academy of Science for organising the conference that led to the writing of this paper.

My gratitude extends to the respondents who were not only available but willing to respond to the questionnaire and engage in the interview

In a special way, I am thankful to all the authors whose works I consulted to come up with this paper.

I am particularly thankful to Dr Wirdze, L. L for analysing the data and for editing this paper.

\section{References}

Bronfenbrenner, U. (1986). Ecology of the family as a context for human development: research perspectives. Developmental Psychology, 22(6), 723742 .

Dwarakesh, B. V., Ananda, D. V., Asifa, N. M., Bhaskar, R. K., \& Brito, R. S. (2020). Novel corona virus-2019 (SARS CoV-2). Int. J Res. Phy. Pharmacol.;10(1): 1-13. 
Erikson, E. H. (1950). Childhood and Society. New York: Norton

Hiebert, P. G., Daniel R. S. \& Tite, T. (2001). Understanding folk religion. Grand Rapids, MI: Baker Books.

Kluge, H. P. (2020) As individuals, family and community members, friends and colleagues" WHO Regional Director for Europe.

Koening, H. G., (2012). Religion, Spirituality, and Health: The Research and Clinical Implications Lazarus, R. S. \& Folkman, S. (1984). Stress, appraisal, and coping. New York: Springer.

Maslow, A. H. (1962). Toward a psychology of being. Princeton: D. Van Nostrand Company.

Maslow, A. H. (1966). Religions, values, and peak experiences. New York: Penguin.

Mbiti, J. S. (1991). Introduction to African religion. Oxford: Heinemann.

Mbiti. J. S. (1969). African Religions and Philosophy. Oxford Heinemann.Ocitti, J. P. (1971). African indigenous education: As practised by the Acholi of Uganda. Nairobi: East African Literature Bureau. Rosmarin, D. (2020). "Why Pandemic Make Us So Anxious". On Everyday Health's video series on the issues of COVID-19 and Mental Health on by Chief editor Maureen Connolly with David Rosmarin, the founder of the Center for Anxiety in New York City and Boston and an assistant professor of psychiatry at Harvard Medical School.

Tchombe M. S. T. (2016). Shifting the Paradigm from misconceptions about Africa's nonproductivity to new narratives on its achievements and contributions: Implications for Research. Journal of Educational Research in Africa
(JERA) Revue Africaine de la Recherche en Éducation (RARE) No. 8, 2016 -13-29.

Tchombe M. S. T., Wirdze, L. L. S., Kuchas, S., Negeng, D. A., Amaazee, B. (2020). Pyschosocial impact and human-interest stories related to COVID19 in the northwest region of Cameroon. Unpublished Practicum Reports, University of Bamenda.

Turnbull, C., M. (1976). Man in Africa: New York, Pelican Books

Van Sertima, I. (1983). "The Lost Sciences of Africa: An Overview." Blacks in Science: Ancient and Modern. 7 - 26

Webography

Cameroon Radio Television (CRTV) (2020). The Archbishop of Douala, His grace Samuel Kleda has made an attempt at treating symptoms of the \#COVID-19 with a herbal remedy, free of charge. http: / / www.crtv.cm/2020/04/ covid-19archbishop-samuel-kleda-proposes-a-herbalremedy/

Latham, J. (2020). The Case Is Building That COVID19 Had a Lab Origin. https:// www.independentsciencenews.org/health/thecase-is-building-that-covid-19-had-a-lab-origin/ Miller, W. R., \& Thoresen, C. E. (1999). Spirituality and health. In W. R. Miller (Ed.), Integrating spirituality into treatment: Resources for practitioners (p. 3-18). American Psychological Association. https://doi.org/10.1037/10327-001

Ministry of Public Health, (2020). The Mechanism set up by the government to effectively respond to the Coronavirus Pandemic. http://www.crtv.cm/2020/ 03/covid-19-the-response-mechanism-unfolds-infour-stages/

Patel, A. \& Jernigan, D. B. (2019). Initial Public Health Response and Interim Clinical Guidance for the 2019 Novel Coronavirus Outbreak-United States, 
December 31, 2019 "February 4, 2020. 2020; 69: 7.

Salve, S. (2020). A Personal Reflection on COVID19's Spiritual Impact. https:// www.internationalhealthpolicies.org/blogs/apersonal-reflection-on-covid-19s-spiritualimpact/

Varshney, M., Parel, J. T., Raizada, N. \& Sarin, S. K. (2020) Initial psychological impact of COVID-19 and its correlates in Indian Community: An online (FEEL-COVID) survey. PLoS ONE 15(5): e0233874. https://doi.org/10.1371/ journal.pone. 0233874

WHO. (2020). Coronavirus disease (COVID-19) pandemic. Press Conference. https:// www.who.int/emergencies/diseases/novelcoronavirus-2019

WHO. (2020). Country \& Technical Guidance Coronavirus disease (COVID-19). https:// www.who.int/emergencies/diseases/novelcoronavirus-2019/technical-guidance

Yao, H. Chen, J. H. \& Xu, Y, F. (2020). Rethinking online mental health services in China during the COVID-19 epidemic. Asian J Psychiatry. 2020; 50: 102015. pmid:32247261. 